\title{
Effects of Gram-positive bacterial pathogens in ewes: peptidoglycan as a potential mediator of interruption of early pregnancy
}

\author{
A. B. Stewart, E. K. Inskeep, E. C. Townsend and R. A. Dailey* \\ Division of Animal and Veterinary Sciences, West Virginia University, PO Box 6108, Morgantown, \\ WV 26506-6108, USA
}

Bacterial cell walls contain peptidoglycan (PTG), which, among other actions, induces fever. The present experiment evaluated the effects of PTG treatment on early pregnancy and blood plasma concentrations of reproductive hormones. Ewes were injected i.v. with saline or 15, 30 or $60 \mu \mathrm{g} \mathrm{kg}^{-1}$ sonicated PTG (Streptococcus pyogenes) on day 5 after mating. Each dose of PTG induced fever. Pregnancy rate at day 25 was not related to incidence of fever but tended to differ among treatments (control, $100 \%$; low, $100 \%$; medium, $67 \%$; high, $60 \%$; $P<0.08$ ). Combined pregnancy rate in ewes from control and low dose groups $(\mathbf{1 0 0} \%)$ was greater than that in ewes from medium and high dose groups $(64 \%, P<0.01)$. Ewes with high 13,14-dihydro-15-keto-prostaglandin $F_{2 \alpha}$ (PGFM) concentrations had lower pregnancy rates (6 of 10) than those with low concentrations of PGFM (11 of 11; $P<0.05)$. Mean cortisol concentrations were higher in treated $\left(2.8 \pm 0.28 \mu \mathrm{g} \mathrm{dl}^{-1}\right)$ than in control $\left(1.1 \pm 0.03 \mu \mathrm{g} \mathrm{dl}^{-1}\right)$ ewes $(P<0.01)$; the pattern of secretion was biphasic and increased in all treated ewes $(P<0.01)$. Neither means nor profiles of oestradiol differed with treatment. Mean concentrations and the pattern of concentrations of progesterone were reduced in all treated ewes, as indicated by the time by treatment and linear interaction with treatment $(1.2 \pm 0.1$ versus $1.6 \pm 0.1 \mathrm{ng} \mathrm{ml}^{-1}, P<0.01$ ). Patterns of $\mathrm{LH}$ pulses did not differ from 0 to $4 \mathrm{~h}$ or 24 to $28 \mathrm{~h}$ after treatment; mean plasma LH concentration was lower in ewes treated with 0,15 or $30 \mu \mathrm{g}$ PTG $\mathrm{kg}^{-1}$ than with $60 \mu \mathrm{g}$ PTG $\mathrm{kg}^{-1}$ $(P<0.01)$. Pregnancy status was not related to plasma concentrations or patterns of $\mathrm{LH}$, oestradiol, progesterone or cortisol. Inflammatory mediators, such as $\mathbf{P G F}_{2 \alpha}$, may act directly on the embryo or uterus in ewes treated with PTG.

\section{Introduction}

Cell growth and lysis of bacteria after bacterial infection result in the release of antigenic cell wall components, leading to increases in inflammatory mediators, which can result in an inflammatory response. For example, Law (1923) observed a general immune response, including fever, in cows with bacterial infection of the udder (mastitis). Cullor (1993) indicated that endotoxin, a component of the cell wall of Gram-negative bacteria, induces luteolysis and reduces conception rate and early embryonic survival through the release of inflammatory mediators. Barker et al. (1998) found that clinical mastitis caused by either Gram-negative or Gram-positive pathogens reduces reproductive performance during early lactation. Each type of pathogen may act through similar mechanisms to increase inflammatory mediators, such as cortisol, interleukin 1 and $\mathrm{PGF}_{2 \alpha}$, leading to reproductive failure.

*Correspondence

Email: rdailey@wvu.edu
Cell walls of both Gram-negative and Gram-positive bacteria contain a mucopeptide, peptidoglycan (PTG; Rotta, 1975). Injections of PTG lead to a pyretic response in rabbits comparable to that elicited by endotoxin (Rotta, 1975). The induced fever is eliminated by treatment with antiserum to PTG. Peptidoglycan is implicated in the induction of acute changes in vascular permeability (Woolverton et al., 1989), similar to those found during endotoxin treatment (Banks, 1999) and experimental mastitis (Matilla and Frost, 1989). Both endotoxin and PTG stimulate the immune system (Rotta, 1975; Lichtman et al., 1994) by crossing the intestinal mucosa and entering the portal veins, subsequently stimulating the release of tumour necrosis factor $\alpha$ (TNF- $\alpha$ ) from Kupffer cells. However, the intracellular signalling pathways for endotoxin and PTG differ (Lichtman et al., 1994).

Increased secretion of $\mathrm{PGF}_{2 \alpha}$ in response to PTG would be expected to decrease pregnancy rate by inducing luteal regression or compromising luteal function. Buford et al. (1996) found that even with replacement therapy with progestagens, luteal regression during days 4-9 after oestrus increased early embryonic 
death in cattle. Cows supplemented with progestagen and treated with $\mathrm{PGF}_{2 \alpha}$ on days 5-8 after mating have lower pregnancy rates $(23 \%)$ compared with controls $(72 \%)$ or cows treated on days $10-13(50 \%)$ or $15-18$ (60\%) (Seals et al., 1998). Similarly, Costine et al. (2001) showed that progestagen-supplemented ewes are sensitive to the embryotoxic effects of $\mathrm{PGF}_{2 \alpha}$ on days 4-7 after mating. Therefore, the early pregnant ewe should be a useful model for evaluation of the effects of PTG on reproductive performance.

The present study tested the null hypothesis that embryonic survival and concentrations of inflammatory mediators and reproductive hormones are not affected by the treatment of ewes with PTG. Specifically, the objective of this study was to evaluate the effect of PTG on (i) pregnancy rate and (ii) concentrations of inflammatory mediators (cortisol and $\mathrm{PGF}_{2 \alpha}$ ) and reproductive hormones ( $\mathrm{LH}$, oestradiol and progesterone) in ewes.

\section{Materials and Methods}

\section{Animals}

Twenty-two ewes of mixed breeding, four years of age or older, were fed haylage and corn silage twice a day and were given free access to fresh water. Oestrus (day 0) was synchronized with two i.m. injections of $5 \mathrm{mg} \mathrm{PGF}_{2 \alpha}$ (Lutalyse; Pharmacia and Upjohn Inc., Kalamazoo, Ml), $3 \mathrm{~h}$ apart (Hawk, 1975). Ewes were observed for oestrus twice a day from synchronization to day 18 using a vasectomized ram, and were mated to two rams of known fertility. Pregnancy diagnosis was carried out on day 25 in ewes that had not returned to oestrus, by transrectal ultrasonography as described by Schrick and Inskeep (1993), using an Aloka 500 console with a $7.5 \mathrm{MHz}$ linear array transducer designed for examination of the human prostate gland (Corometrics Medical Systems, Wallingford, CT). Use of animals in this study was approved by the West Virginia University Institutional Animal Care and Use Committee as protocol \#9801-06.

\section{Dose determination and treatments}

Solubilized PTG, isolated from the Gram-positive pathogen Streptococcus pyogenes, was obtained from Lee Laboratories (Grayson, GA). A single dose of PTG results in a pronounced inflammatory response in rats (Lee Laboratories, personal communication). Therefore, ewes received a single injection (i.v.) of PTG. All ewes were treated on day 5 after mating. Luteolysis is induced in cows with $1.5 \mu \mathrm{g}$ endotoxin $\mathrm{kg}^{-1}$ body weight (BW) (Gilbert and Bosu, 1990). Treatment of goats with $1.8 \mu \mathrm{g}$ endotoxin $\mathrm{kg}^{-1} \mathrm{BW}$ induces luteolysis; however, treatment with $1.5 \mu \mathrm{g}$ endotoxin $\mathrm{kg}^{-1} \mathrm{BW}$ is ineffective (Fredricksson et al., 1985). Rotta (1975) determined that $150 \mu \mathrm{g}$ PTG elicits a pyretic response in rabbits comparable to that induced by $5 \mu$ gendotoxin. Therefore, $60 \mu \mathrm{g}$ PTG (equivalent to $2 \mu \mathrm{g}$ endotoxin) would be expected to induce fever and luteolysis and $15 \mu \mathrm{g}$ PTG (equivalent to $0.5 \mu \mathrm{g}$ endotoxin) would not be expected to induce fever or luteolysis. Ewes were assigned at random to one of four treatments: control, saline only $(n=5)$; low, $15 \mu \mathrm{g}$ PTG kg-1 BW $(n=6)$; medium, $30 \mu \mathrm{gPTG} \mathrm{kg}{ }^{-1} \mathrm{BW}(n=6)$; or high dose, $60 \mu \mathrm{g}$ PTG kg ${ }^{-1}$ BW $(n=5)$. Rectal body temperature was taken hourly from 0 to $4 \mathrm{~h}$ and at 8,12 and $24 \mathrm{~h}$ after treatment.

\section{Assays}

Samples of jugular blood $(10 \mathrm{ml})$ were collected into heparinized tubes every $15 \mathrm{~min}$ from 0 to $4 \mathrm{~h}$ and 24 to $28 \mathrm{~h}$ after treatment for $\mathrm{LH}$ determinations. Samples were collected every $4 \mathrm{~h}$ up to $48 \mathrm{~h}$ and daily to day 18 for determinations of the other hormones. Samples were centrifuged at $1000 \mathrm{~g}$ for $20 \mathrm{~min}$ and plasma was stored at $-20^{\circ} \mathrm{C}$. Validated radioimmunoassays were used to determine concentrations of progesterone (Sheffel et al., 1982), oestradiol (Rozell and Keisler, 1990), LH (Fogwell et al., 1978), cortisol (human cortisol, radioimmunoassay kit; Diagnostic Products Corporation, Los Angeles, CA) and 13,14dihydro-15-keto-prostaglandin $\mathrm{F}_{2 \alpha}$ (PGFM; Silvia and Taylor, 1989). For each hormone, all samples (200 $\mu \mathrm{l}$ in duplicate) from an animal were included in one assay. Intra- and interassay coefficients of variation $(\mathrm{CVs})$ for progesterone, oestradiol, $\mathrm{LH}$ and PGFM were 9.6 and 20.5, 5.3 and 18, 10.9 and 17.4 , and 4.4 and $2.9 \%$, respectively. Concentrations of cortisol were determined in a single assay, with an intra-assay CV of $11.5 \%$. Sensitivities for the assays were $0.1 \mathrm{ng} \mathrm{m}^{-1}, 0.5 \mathrm{pg} \mathrm{ml}^{-1}$, $0.5 \mathrm{pg} \mathrm{ml}^{-1}, 10 \mathrm{pg} \mathrm{ml}^{-1}$ and $0.5 \mathrm{\mu g} \mathrm{dl}^{-1}$ for progesterone, oestradiol, LH, PGFM and cortisol, respectively.

\section{Statistical analyses}

Pulse patterns of LH were examined by PC-Pulsar (Gitzen and Ramierez, 1986). Concentrations of hormones were examined by ANOVA and pregnancy rates were examined by pointe biserial correlation (SAS Institute Inc., 1989). For PGFM, variances differed among treatments and time periods, thus a weighted ANOVA was used. Each observation was weighted by the inverse of the variance among observations within a given treatment and time period. Days were grouped into four periods, each consisting of four or five observation days, for the purpose of calculating variances.

Association of treatment with incidence of fever was analysed by chi-squared test (SAS Institute Inc., 1989). The assumptions of normality and homogeneity of variances were not met, and the data did not follow a linear model, because the concentrations of PGFM of 

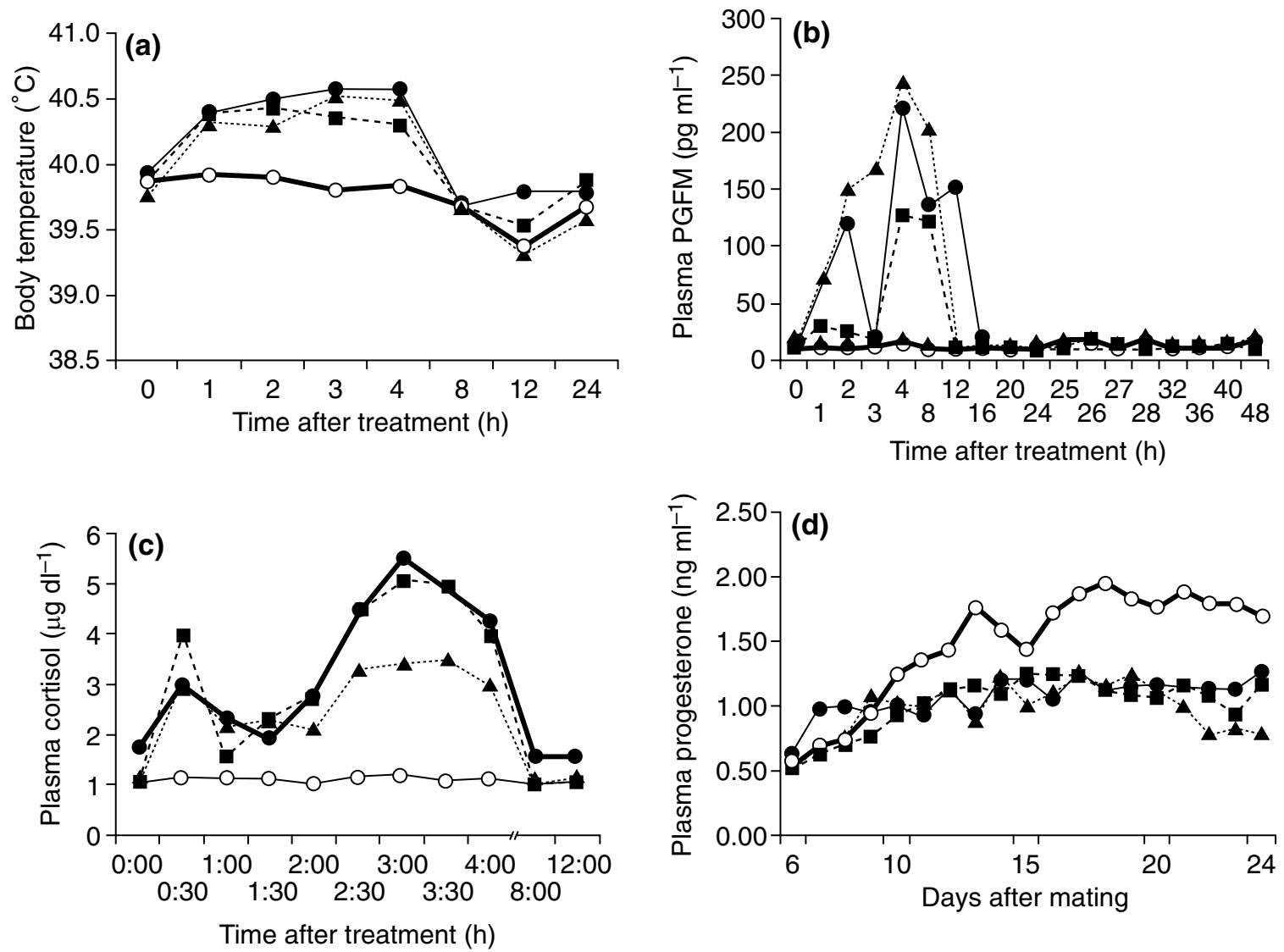

Fig. 1. (a) Body temperature (fever response) in ewes after treatment with peptidoglycan (PTG). Fever (body temperature increase $>0.5^{\circ} \mathrm{C}$ ) occurred in treated (13 of 17) but not in control ewes $(0$ of $5 ; P<0.01 ; \mathrm{SEM}=0.23)$. (b) Concentrations of 13,14-dihydro-15-keto PGF $_{2 \alpha}$ (PGFM) in ewes did not differ as a result of treatment with PTG. (c) Concentrations of cortisol differed between control ewes and ewes treated with PTG $(P<0.01$; SEM $=0.77)$. (d) Concentrations of progesterone were reduced in all ewes treated with PTG $(P<0.01$; SEM $=0.37)$. (a-d) Groups were as follows: control

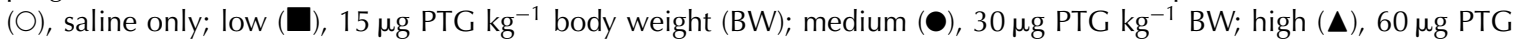
$\mathrm{kg}^{-1} \mathrm{BW}$.

many ewes were not detectable $\left(<10 \mathrm{pg} \mathrm{ml}^{-1}\right)$. Thus, Fisher's exact test (Finney et al., 1963) was used to determine the effects of PGFM classification (low and high $50 \%$ groups based on concentrations of PGFM) on pregnancy status.

\section{Results}

Haematocrits were similar in all ewes throughout the sampling period. Fever (body temperature increase $>0.5^{\circ} \mathrm{C}$ ) occurred in treated (13 of 17) but not in control ewes $(0$ of $5 ; P<0.01)$. Body temperature peaked at $4 \mathrm{~h}$ and returned to pre-treatment values by $8 \mathrm{~h}$ after PTG treatment (Fig. 1a). However, pregnancy rate was not related to incidence of fever (ewes with fever: 10 of 13 pregnant; ewes with no fever: 8 of 9 pregnant). Pregnancy rate tended to differ among treatments but the effect was not significant (control, 100\%; low, 100\%; medium, $67 \%$; high, $60 \% ; P<0.08)$. Combined pregnancy rate in ewes from control and low dose groups $(100 \%)$ was greater than that in ewes from medium and high dose groups $(64 \%, P<0.01)$.

Mean concentrations and profiles of PGFM did not differ with treatment $(P>0.10$; Fig. 1b). Pregnancy rate was lower in ewes with high concentrations of PGFM (6 of 10) than in ewes with low concentrations of PGFM (11 of $11 ; P<0.05)$. Concentrations or patterns of the other hormones were not associated with pregnancy status. The pattern of cortisol secretion was biphasic and increased in all ewes treated with PTG $(P<0.01$; Fig. 1c). Mean concentrations of cortisol were higher in treated than in control ewes $\left(2.8 \pm 0.28\right.$ versus $\left.1.1 \pm 0.03 \mu \mathrm{gdl}^{-1} ; P<0.01\right)$. Mean concentrations of $\mathrm{LH}$ were lower $(P<0.01)$ in ewes treated with 0,15 or $30 \mu \mathrm{g}$ PTG $\mathrm{kg}^{-1}(0.9 \pm 0.1$, $1.2 \pm 0.1$ and $0.9 \pm 0.1 \mathrm{ng} \mathrm{ml}^{-1}$, respectively) than with $60 \mu \mathrm{g}$ PTG kg ${ }^{-1}\left(1.9 \pm 0.1 \mathrm{ng} \mathrm{ml}^{-1}\right)$. However, characteristics of $\mathrm{LH}$ pulses did not differ. Mean concentrations $\left(1.2 \pm 0.1\right.$ versus $1.6 \pm 0.1 \mathrm{ng} \mathrm{ml}^{-1} ; P<$ 0.01 ) and the pattern of concentrations of progesterone 
were reduced in all treated ewes, as indicated by the time (h) by treatment and linear interaction with treatment (Fig. 1d). Neither mean concentrations nor patterns of oestradiol differed as a result of treatment. Concentrations of oestradiol for all ewes averaged $2.5 \pm 0.1 \mathrm{pg} \mathrm{ml}^{-1}$.

\section{Discussion}

Peptidoglycan-induced pyretic response was achieved in the present study, as $76 \%$ of ewes treated with PTG responded with a fever. The response was acute; body temperature peaked at $4 \mathrm{~h}$ and returned to baseline by $8 \mathrm{~h}$. Although the profile in the present study was monophasic, endotoxin or PTG produces a biphasic pyretic response in rabbits (Rotta, 1975). Changes in mean concentrations of cortisol are biphasic and similar to those found in men after induced hyperthermia (Collins et al., 1969). Cortisol has been shown to decrease release of pyrogenic substances from leucocytes (Gander et al., 1968; Dillard and Bodel, 1970). It is possible that concentrations of cortisol increased in response to fever and controlled the pyretic response. Incidence of fever and concentrations of cortisol were increased in all treatment groups. Pregnancy loss in treated ewes was not a function of fever or concentration of cortisol per se, because ewes receiving the low dose of PTG maintained pregnancy even though they showed fever and had high concentrations of cortisol.

Loss of pregnancy could occur through decreased luteal function. Secretion of LH is decreased in studies with endotoxin treatment (Stoebel and Moberg, 1982; Lopez-Diaz and Bosu, 1992). Corticotropin-releasing factor (Lopez-Diaz and Bosu, 1992) and adrenocorticotropic hormone (Besedosbky et al., 1986) increase after a challenge of endoxin and either by acting directly or through increases in cortisol, can decrease LH secretion (Besedosbky et al., 1986; Lopez-Diaz and Bosu, 1992; Cullor, 1993). However, in the present study, PTG treatment did not affect the pattern of secretion of $\mathrm{LH}$; in fact, mean LH was greater in ewes receiving the high dose of PTG. In addition, treatment with PTG did not affect mean concentrations or pattern of oestradiol. Thus, embryo mortality was not related to increased systemic concentrations of oestradiol, as observed previously during maternal recognition of pregnancy in cattle (Pritchard et al., 1994), nor to reduced concentrations of LH.

PTG treatment results in decreased concentrations of progesterone at each dose. However, ewes in the low dose group maintained pregnancy despite decreased progesterone. PTG treatment may have resulted in inadequate formation of corpora lutea, and the subsequent loss of other factors may have resulted in loss of pregnancy.

It is possible that treatment with PTG resulted in the synthesis or release of additional inflammatory mediators that could act directly on the embryo. Increases in $\mathrm{PGF}_{2 \alpha}$ occur after treatment with endotoxin (Giri et al., 1984, 1991; Fredricksson et al., 1985; Cort and Kindahl, 1990; Cullor, 1993). Costine et al. (2001) showed that progestagen-supplemented ewes are sensitive to the embryotoxic effects of $\mathrm{PGF}_{2 \alpha}$ on days $4-7$ after mating. Although in the present study mean concentrations and profiles of PGFM did not differ due to treatment, pregnancy was maintained in only six of ten ewes with high plasma concentrations of PGFM, but in all ewes with lower PGFM. Increases in $\mathrm{PGF}_{2 \alpha}$ were insufficient to induce luteolysis. It is possible that $\mathrm{PGF}_{2 \alpha}$ has direct adverse effects on the embryo. In addition, increases in acute phase proteins such as tumour necrosis factor $\alpha$ (TNF- $\alpha$ ) may affect embryonic survival directly after PTG treatment, as in vitro culture of preimplantation mouse embryos with TNF- $\alpha$ results in the absence of embryos reaching the blastocyst stage and decreased total cell number (Kurzawa et al., 2001).

Redl et al. (1989) compared the effects of lipopolysaccharide and PTG on cardiovascular function in ewes. To date there is no reported work evaluating the effects of PTG on reproductive function in ewes. The goal of the present study was to examine whether Gram-positive pathogens, like the extensively studied Gram-negative pathogens, can have adverse effects on reproduction. The fever and cortisol data from the present study demonstrate that PTG treatment results in an immune response. Pregnancy loss was not due to fever, increased cortisol and decreased progesterone, as ewes in the low dose group maintained pregnancy despite these changes. Instead, inflammatory mediators such as $\mathrm{PGF}_{2 \alpha}$ and TNF- $\alpha$, which could act directly on the embryo, might adversely affect embryonic survival after PTG treatment in ewes.

The authors wish to thank NIADDK for NIADDK-oLH26; Lee Laboratories (Grayson, GA) for technical support with PTG; Pharmacia Corporation (Peapack, NJ) for PGF $_{2 \alpha}$ used to synchronize oestrus; W. Silvia (University of Kentucky, Lexington, KY) for assays of PGFM; and W. Thayne and G. Seidel for assistance with statistical analyses.

Published with the approval of the Director of the West Virginia Agricultural and Forestry Experiment Station as Scientific Paper No. 2827 from the Division of Animal and Veterinary Science. This investigation was supported by West Virginia Hatch Project 321.

\section{References}

Banks WA, Kastin AJ, Brennan JM and Vallance KL (1999) Adsorbtive endocytosis of HIV-1gp120 by blood-brain barrier is enhanced by lipopolysaccharide Experimental Neurology 165 165-171

Barker AR, Schrick FN, Lewis MJ, Dowlen HH and Oliver SP (1998) Influence of clinical mastitis during early lactation on reproductive performance of Jersey cows Journal of Dairy Science 81 1285-1290

Besedosbky H, del Rey A, Sorkin E and Dinarello CA (1986) Immunoregulatory feedback between interleukin-1 and glucocorticoid hormones Science 233 652-654 
Buford WI, Ahmad N, Schrick FN, Butcher RL, Lewis PE and Inskeep EK (1996) Embryotoxicity of a regressing corpus luteum in beef cows supplemented with progestogen Biology of Reproduction 54 531-537

Collins KJ, Few JD, Forward TJ and Giec LA (1969) Stimulation of adrenal glucocorticoid secretion in man by raising the body temperature Journal of Physiology 202 645-660

Cort N and Kindahl H (1990) Endotoxin-induced abortion in early pregnant gilts and its prevention by flunixin meglumine Acta Veterinaria Scandinavica 31 347-358

Costine BA, Sayre BL and Inskeep EK (2001) Embryotoxicity of regressing corpora lutea in ewes Reproduction 122 883-887

Cullor JS (1993) Mastitis and its influence upon reproductive performance in dairy cattle p 176 Proceedings of the International Symposium on Bovine Mastitis Indianapolis, IN. National Mastitis Council Inc. and American Association of Bovine Practitioners, Arlington, VA

Dillard GM and Bodel P (1970) Studies on steroid fever. II. Pyrogenic and anti-pyrogenic activity in vitro of some endogenous steroids of man Journal of Clinical Investigation 49 2418-2426

Finney DJ, Latscha R, Bennett BM and Hsu P (1963) Tables for Testing Significance in a 2 × 2 Contingency Table Cambridge University Press, New York

Fogwell RL, Weems CW, Lewis GS and Inskeep EK (1978) Secretion of steroids after induced luteal regression in beef heifers: effects of PGF $_{2 \alpha}$ and removal of corpora lutea Journal of Animal Science $\mathbf{4 6} 1718-1723$

Fredricksson G, Kindahl J and Edquist LE (1985) Endotoxin-induced prostaglandin release and corpus luteum function in goats Animal Reproduction Science 8 109-121

Gander GW, Brown RE and Goodale F (1968) Mechanism of the antipyretic action of glucocorticoids Endocrinology 82 195-198

Gilbert RO and Bosu WTK (1990) The effect of Escherichia coli endotoxin on luteal function in Holstein heifers Theriogenology 33 645-651

Giri SN, Chen Z, Carroll EJ, Mueller R, Schiedt MJ and Panico L (1984) Role of prostaglandins in pathogenesis of bovine mastitis induced by Escherichia coli endotoxin American Journal of Veterinary Research 45 586-591

Giri SN, Stabenfeldt GH, Mosley TA, Graham TW, Bruss ML, BonDurant RH, Cullor JS and Osburn BI (1991) Role of eicosanoids in abortion and its prevention by treatment with flunixin meglumine in cows during the first trimester of pregnancy Journal of Veterinary Medicine Series A 38 445-459

Gitzen JF and Ramierez VD (1986) PC-Pulsar: Pulsar for the IBM-PC Operating Instructions Neural and Behavioral Biology Program and Department of Physiology and Biophysics, University of Illinois, Urbana, IL

Hawk HW (1975) Enhancement by exogenous estradiol of uterine motility in estrous ewes Journal of Animal Science 41 572-577

Kurzawa, R, Glabowski, W and Wenda-RóGewicka L (2001) Evaluation of mouse preimplantation embryos cultured in media enriched with insulin-like growth factors I and II, epidermal growth factor and tumor necrosis factor Folia Histochemica et Cytobiologica 39 245-251

Law J (1923) Diseases Following Parturition. Special Report on Diseases of Cattle pp 234-235 US Department of Agriculture, Bureau of Animal Industry. Government Printing Office, Washington DC

Lichtman SN, Wang J, Schwab JH and Lemasters JJ (1994) Comparison of the peptidoglycan-polysaccharide and lipopolysaccharide stimulation of Kupffer cells to produce tumor necrosis factor and interleukin-1 Hepatology 19 1013-1022

Lopez-Diaz MC and Bosu WTK (1992) A review and update of cystic ovarian degeneration in ruminants Theriogenology 37 1163-1183

Mattila T and Frost AJ (1989) Induction by endotoxin of the inflammatory response in the lactating and dry bovine mammary gland Research in Veterinary Science $\mathbf{4 6} 238-240$

Pritchard JY, Schrick FN and Inskeep EK (1994) Relationship of pregnancy rate to peripheral concentrations of progesterone and estradiol in beef cows Theriogenology $\mathbf{4 2} 247$

Redl H, Schlag G, Thurnher M, Traber LD and Traber DL (1989) Cardiovascular reaction pattern during endotoxin or peptidoglycan application in awake sheep Circulatory Shock 28 101-108

Rotta J (1975) Endotoxin-like properties of the peptidoglycan Zeitschrift fur Immunitatsforschung, Experimentelle und Klinische Immunologie 149 230-244

Rozell TG and Keisler DH (1990) Effects of oestradiol on LH, FSH and prolactin in ovariectomized ewes Journal of Reproduction and Fertility 88 645-653

SAS Institute Inc. (1989) SAS User's Guide: Statistics, version 6.06 SAS Institute Inc., Cary, NC

Schrick FN and Inskeep EK (1993) Determination of early pregnancy in ewes utilizing transrectal ultrasonography Theriogenology 40 295-306

Seals RC, Lemaster JW, Hopkins FM and Schrick FN (1998) Effects of elevated concentrations of prostaglandin $F_{2 \alpha}$ on pregnancy rates in progestogen supplemented cattle Prostaglandins and Other Lipid Mediators $\mathbf{5 6} 377-389$

Sheffel CE, Pratt BR, Ferrell WL and Inskeep EK (1982) Induced corpora lutea in the postpartum beef cow. II. Effects of treatment with progestogen and gonadotropins Journal of Animal Science 54 830-836

Silvia WJ and Taylor ML (1989) Relationship between uterine secretion of prostaglandin $\mathrm{F}_{2 \alpha}$ induced by oxytocin and endogenous concentrations of estradiol and progesterone at three stages of the bovine estrous cycle Journal of Animal Science 67 2347-2353

Stoebel DP and Moberg GP (1982) Effect of adrenocorticotropin and cortisol on luteinizing hormone surges and estrus behavior of cows Journal of Dairy Science 65 1016-1024

Woolverton CJ, White JJ, Jr and Sartor RB (1989) Eicosanoid regulation of acute intestinal vascular permeability induced by intravenous peptidoglycan-polysaccharide polymers Agents Actions 26 301-309

Received 27 June 2002.

First decision 7 August 2002.

Revised manuscript received 14 October 2002.

Accepted 18 October 2002. 